Indonesian Journal of Medicine (2019), 4(3): 278-284

https://doi.org/10.26911/theijmed.2019.04.03.11

\title{
Yoga Increases the Quality of Sleep in Menopause Women
}

\author{
Yetty Dwi Fara',3), Rr. Sri Endang Pujiastuti²), Suharyo Hadisaputro²) \\ ${ }^{1)}$ Midwifery Program, School of Health Polytechnics Semarang \\ 2)School of Health Polytechnics Semarang \\ 3) School of Health Sciences Aisyah, Pringsewu Lampung
}

\begin{abstract}
Background: Menopausal women experience various changes, physical, psychological, and hormonal changes that cause menopausal symptoms. During menopause, women experience sleep disorders and some experience insomnia. Lifestyle changes are one way to reduce menopausal symptoms, such as physical activity. Physical activities such as yoga can stimulate a relaxation response both physically and psychologically that can reduce physical and psychological symptoms in menopausal women. The aim of this study was to examine the effect of yoga interventions on the sleep quality of menopausal women.

Subjects and Method: This was a quasi-experiment with a non-equivalent control group design. The study was conducted in the Gedawang-Banyumanik area, Semarang, Central Java. A total of 22 study subjects was collected by purposive sampling. The dependent variable was quality of sleep. The independent variable was yoga. The quality of sleep was measured using Pittsburgh Sleep Quality Index (PSQI).

Results: Poor quality of sleep score decreased by 10.73 after yoga intervention ( $95 \% \mathrm{CI}=-4.30$ to $0.26 ; \mathrm{p}=0.029$ ).

Conclusion: Yoga interventions improve the quality of sleep in menopausal women.
\end{abstract}

Keywords: quality of sleep, yoga, meopausal women

\section{Correspondence:}

Yetty Dwi Fara. Midwifery Program, School of Health Polytechnics Semarang. Jl. Tirto Agung Pedalangan, Banyumanik, Semarang, Central Java, 50239. Email: yettydwifara@gmail.com. Mobile: 085279545189.

\begin{abstract}
BACKGROUND
Menopause is a biological process that marks the end of a woman's fertile period, namely the cessation of the menstrual cycle. The cessation of menstruation will have a direct and indirect impact on the physical and psychological health consequences. Stop menstruation is associated with increasing age in women, ovarian function will decrease in forming follicles, resulting in changes in several hormones such as increased levels of folliclestimulating hormone (FSH) with normal estrogen levels. Follicles that can no longer develop, resulting in estrogen levels will decline so that women stop menstruating (Irianto, 2015). Changes in the release of hormones cause various complaints on
\end{abstract}

physical and psychological in menopausal women, one of the complaints that are often felt is sleep disturbances that cause reduced the quality of sleep. Reduced sleep time due to sleep disturbances experienced by menopausal women have a negative effect if left in the long term, which results in the death of working parts of the brain that regulate language skills, remembering, and sensitivity to time (Comfort, 2010). Irregular sleep patterns can also result insufficient quality and quantity of sleep that can damage memory and cognitive abilities so that it has an impact on high blood pressure, heart attacks, and strokes (Maryam, 2008).

Physical symptoms during menopause include hot flushes and night sweats 
(Women's Health Concern, 2015). The heat felt by menopausal women results in an increase in blood pressure both systolic and diastolic (Proverawati and Sulistyawati, 2010). In addition, night sweats experienced at menopause will disrupt sleep patterns, resulting in insomnia is a sleep disorder (PERMI Jawa Barat 2013). During menopause, $50 \%$ of women experience sleep disturbances and 60\% of them experience insomnia(Van Dijk et al., 2015; Wijayanti et al., 2014).

One of the efforts to improve the health quality of menopause is by improving the quality of health services that are focused on protecting high-risk groups, including menopausal women. Women who experience menopause belong to the group at risk because in menopausal women there are drastic changes in physical, psychological, and socio-cultural. One of the roles of health workers in addition to providing education and counseling is to form a forum for postmenopausal women who have physical activities (Suparni \& Astutik, 2016). Activities or physical activities can be done with sports or gymnastics.

Previous study showed that yoga has many health benefits. Doing yoga can stimulate the relaxation response both physically and psychologically (Moilanen et al., 2010).

This response is due to the stimulation of the parasympathetic autonomic nervous system activity of raphe nuclei which is located in the lower half of the pons and in the medulla resulting in a decrease in body metabolism, pulse, pressure blood, respiratory frequency, and increased serotonin (Lebang, 2013).

Increased serotonin levels cause the body to relax so as to improve the quality of sleep. Based on this background, this study aims to prove whether yoga interventions improve the quality of sleep.

\section{SUBJECTS AND METHOD}

\section{Study Design}

This was aquasi-experimental with nonequivalent control group design. This study was conducted in Gedawang-Banyumanik area, Semarang, Central Java, Indonesia.

\section{Population and Sample}

Population study was postmenopausal women aged 40 to 55 years, who met the following:

a. Inclusion Criteria

1) Amenorrhea for 3 months or more

2) No physical limitations to physical activity

3) Normal blood pressure (systolic $<130$ $\mathrm{mmHg}$ and diastolic $<85 \mathrm{mmHg}$ ) to hypertension stage 1 (systolic 140-159 $\mathrm{mmHg}$ or diastolic 90-99 $\mathrm{mmHg}$ )

b. Exclusion criteria

1) Use hormonal therapy/ medication for the past 6 months

2) Being in psychoactive drug treatment/ psychiatry

A sample of of 22 study subjects was divided into two groups. In the treatment group, respondents received menopausal education and yoga intervention 8 times for 4 weeks with duration of 60 minutes. In the control group, study subjects received menopausal education.

\section{Study Variables}

The dependent variable was quality of sleep. The independent variable was yoga.

\section{Study Instrument}

Instrument for this study was Pittsburgh Sleep Quality Index (PSQI) questionnaire to measure the quality of sleep.

\section{Data Analysis}

The data were analyzed by univariate analysis to see the frequency of sample characteristics. Bivariate analysis was to analyze differences in the quality of sleep scores in each group using paired sample t-test, while between groups using independentsamples t-test. 


\begin{tabular}{|c|c|c|c|c|c|}
\hline \multicolumn{6}{|c|}{$\begin{array}{ll}\text { 1. Samples Characteristic } & \text { treatment group and } 81.8 \% \text { in the control } \\
\text { Table } 1 \text { showed that in both groups, most of } & \text { group. Both groups have the same (homo- } \\
\text { the education from study subjects was high } & \text { geneous). } \\
\text { school graduates ( } 45 \cdot 5 \% \text { ), respondents with } \\
\text { Table 1. Sample Characteristics by Education and Employment }\end{array}$} \\
\hline \multirow{2}{*}{ Independent Variables } & \multicolumn{2}{|c|}{ Intervention } & \multicolumn{2}{|c|}{ Control } & \multirow[t]{2}{*}{$\mathbf{p}$} \\
\hline & $\mathbf{n}$ & $\%$ & $\mathbf{n}$ & $\%$ & \\
\hline Education Status & & & & & 0.753 \\
\hline No education & $\mathrm{O}$ & O & o & o & \\
\hline Elementary school & 1 & 9.1 & 2 & 18.2 & \\
\hline Junior high school & 3 & 27.3 & 3 & 27.3 & \\
\hline Senior high school & 5 & $45 \cdot 5$ & 5 & $45 \cdot 5$ & \\
\hline Diploma/College & 2 & 18.2 & 1 & 9.1 & \\
\hline Job Status & & & & & 0.233 \\
\hline Work & 1 & 9.1 & 2 & 18.2 & \\
\hline Not working & 10 & 90.9 & 9 & 81.8 & \\
\hline
\end{tabular}

Table 2. Differences in the quality of sleep

\begin{tabular}{lccccc}
\hline \multirow{2}{*}{ Variables } & \multicolumn{2}{c}{ Treatment } & \multicolumn{2}{c}{ Control } \\
\cline { 2 - 6 } & & Mean & SD & Mean & SD \\
\hline \multirow{2}{*}{ Scores quality of sleep } & Before & 17.18 & 7.78 & 12.64 & 5.40 \\
\multirow{2}{*}{$\begin{array}{l}\text { Difference score the quality of sleep } \\
\text { p }\end{array}$} & 6.45 & 2.62 & 8.73 & 1.84 \\
$\mathrm{p}$ & 10.73 & 8.65 & 3.91 & 5.48 \\
\hline
\end{tabular}

Table 2 showed that there was a significant difference of anxiety scores between groups before and after treatment. Quality of sleep score was higher in treatment group (mean $=10.73 ; \mathrm{SD}=8.65)$ than control group $($ mean $=3.91 ; \mathrm{SD}=5.48)$

Table 3. Differences of quality of sleep between intervention and control groups after intervention

\begin{tabular}{lllllll}
\hline \multicolumn{1}{c}{ Variables } & \multicolumn{1}{c}{ Group } & Mean & SD & $\begin{array}{c}\text { Lower } \\
\text { limit }\end{array}$ & $\begin{array}{c}\text { Upper } \\
\text { limit }\end{array}$ & p \\
\hline Score of quality of & Intervention & 6.45 & 2.62 & -4.29 & -0.26 & 0.029 \\
sleep & Control & 8.73 & 1.84 & & & \\
Score Difference in the & Intervention & 10.73 & 8.65 & -13.26 & -0.38 & 0.039 \\
quality of sleep scores & Control & 3.91 & 5.48 & & & \\
\hline
\end{tabular}

Table 3 showed the differences of quality of sleep between intervention and control groups after intervention. Based on table 3 , the results of the independent test obtained $\mathrm{p}<0.05$ and confidence intervals did not cross the zero point, which means that it was statistically differences in the quality of sleep scores after interventions between treatment group with control group. 


\section{DISCUSSION}

1. Sample Characteristics

\section{a. Education}

Results of this study indicate that the characteristics of respondents based on education level were mostly high school level (45.5\%) in the treatment and control groups. The results of the study showed that both groups had homogeneous variant. The level of education is indirectly related to health, where the level of education determines awareness, attitude, behavior, and knowledge of health. Education is closely related to knowledge, the higher the level of education, the easier it will be to receive and develop knowledge (Sabatini, 2016).

The level of one's education is related to one's ability to receive information and analyze and process it into knowledge. The higher the level of one's education, the easier it will be to receive information (Nursalam, 2008). Every woman who enters menopause has adequate knowledge of menopause can undergo menopause more readily. Readiness of menopausal women is seen from the good information obtained about changes and symptoms that are felt during menopause.

\section{b. Employment}

The results of this study indicate that most of the respondents were housewives who did not work $90.9 \%$ in the treatment group and $81.8 \%$ in the control group. Work is a time-consuming activity, women who work will have less time to pay attention to their families and themselves because some of their time is done to work. As a housewife, problems can be present from oneself and from the outside environment that can trigger stress that can cause high blood pressure (hypertension) (Fatimah, 2014). Domestic work can aggravate the physical changes felt by menopausal women. Housewife's work cannot be underestimated because the work can be done from waking up to sleeping again, and not work that can be considered easy to do. Women's physical activity and knowledge about menopause can affect the physical and psychological changes in menopausal women (Proverawati and Sulistyawati, 2010).

\section{Benefits of yoga on the quality of sleep of menopausal women}

The results showed that there was a decrease in the quality of sleep scores after yoga intervention, the difference in mean scores before and after yoga is done at 10.73. The quality of sleep score is said to be good if you get a score of $\leq 5$, the smaller the number of scores, the better the quality of sleep. Sleep difficulties are a health problem that is disruptive and needs to be anticipated during menopause. Physical and psychological changes experienced during menopause cause anxiety, fear, and anxiety that can cause insomnia or sleep disturbances (Proverawati and Sulistyawati, 2010; Bankar et al., 2013).

Changes in estrogen levels during menopause also affect other body functions that are controlled by estrogen. Estrogen has an effect on the quality of sleep, estrogen receptors are found in the brain that regulate sleep (Baziad, 2003). One symptom of a decrease in the amount of estrogen is a hot flush, during menopause this symptom is also accompanied by night sweats which cause women wake up from sleep (Proverawati and Sulistyawati, 2010). These symptoms will interfere with sleep which causes menopausal women to experience sleep deprivation that will affect the quality of sleep (Lestari, 2010).

Test results of independent sample-t tests that show that there is an influence of yoga intervention on the quality of sleep in postmenopausal women after yoga intervention for 8 times for 4 weeks with duration of 60 minutes. Yoga can stimulate 
Indonesian Journal of Medicine (2019), 4(3): 278-284

https://doi.org/10.26911/theijmed.2019.04.03.11

relaxation responses both physically and psychologically. This response resulted in an increase in serotonin which causes the body to relax so as to improve the quality of sleep (Lebang, 2013). The results of this study are in line with previous studies on the effect of yoga on the quality of sleep in postmenopausal women showing that yoga improves the quality of sleep with $\mathrm{p} \leq 0.001$ after yoga treatment (Nurdiati et al., 2015).

Physical exercise or what is known as exercise is a physical action to strengthen health or improve physical deformity, physical exercise for at least 30 minutes can stimulate the release of endorphins and reduce levels of the hormone cortisol in the body will cause mental balance. One type of exercise that is often applied is yoga which is a holistic health system, through yoga one will be better able to know his body, know his mind and know his soul (Shindu, 2013).

There are various poses in yoga, one of which is appose restorative which can provide a deep resting state. The yoga movement can help insomniacs to sleep well because it can have a positive influence on the brain's nerve center which will release stiffness in the muscles in the body and provide peace of mind and ultimately help to sleep (Shindu, 2013; Harpen et al., 2014).

Pranayama or breathing techniques, increase the intake of oxygen and prana into the body, improve the function of the body's cells, and increase the concentration and calmness of the mind. Mastering breathing means mastering emotions and thoughts. When the uncontrolled breathing of emotions becomes turbulent, the muscles of the body will tighten causing difficulty in starting sleep. Conversely, with gentle breathing regularly, the mind will become calmer, emotions will be filled with tranquility, and the body becomes more

relaxed (Shindu, 2013).

Feelings of calm and comfort can lead to drowsiness so that the elderly can easily start sleeping. The ease of initiating sleep will have an impact on the length of sleep, by sleeping earlier than usual and the time to enter a shorter sleep will immediately prolong sleep (Ohayon et al., 2010).

Based on the results of this study, yoga intervention for 8 times for 4 weeks with duration of 60 minutes has an effect on improving the quality of sleep of menopausal women. The results of this study are expected to develop menopause care, so yoga is used as one of the choices of physical activity activities in menopausal midwifery care.

\section{AUTHOR CONTRIBUTIONS}

Yetty Dwi Fara selected the study subjects, collected the data, measured quality of sleep, and wrote the manuscript. Sri Endang Pujiastuti gave theoretical suggestion on the effect of yoga on quality of sleep. Suharyo Hadisaputro did the data analysis and interpreted the results of data analysis.

CONFLICT OF INTEREST

We declare that we do not have any conflict of interest.

FUNDING AND SPONSORSHIP

There is no external fund and sponsorship.

ACKNOWLEDGEMENT

We would like to thank Central Java Provincial Health Office for giving permission to collect the data. Thanks to the study subjects in Gedawang, Banyumanik, Semarang, Central Java, who participated in this study.

\section{REFERENCE}

Bankar MA, Chaudhari SK, Chaudhari KD (2013). Impact of long term Yoga 
practice on sleep quality and quality of life in the elderly. J Ayurveda Integr Med. 2013 Jan-Mar; 4(1): 2832. doi: 10.4103/0975-9476.109548.

Baziad A (2003). Menopause dan Andropause Edisi 1. Jakarta: Yayasan Bina Pustaka Sarwono Prawirohardjo.

Comfort R, Chatarina C (2010). Mengatasi Insomnia: Kiat Praktis dan Alkitabiah untuk Membantu Orang yang Sulit Tidur. Jakarta: BPK Gunung Mulia.

Hakked CS, Balakrishnan R, Krishnamurthy MN (2017). Yogic breathing practices improve lung functions of competitiveyoung swimmers. Journal of Ayurveda and Integrative Medicine, 8: 99-104. http://dx.doi.org/10.1016/j.jaim.2016.12.005.

van Dijk GM, Kavousi M, Troup J, Franco $\mathrm{OH}$ (2015). Health issues for menopausal women: The top 11 conditions have common solutions. Maturitas. 80(1): 24-30. doi: 10.1016/j.maturitas.2014.09.013

Fatimah D (2014). Perbedaan Stres pada ibu rumah tangga yang bekerja dengan ibu rumah tangga yang tidak bekerja di kelurahan Labuh Baru Barat. Universitas Islam Negeri Sultan Sarif Kasim Riau. Skripsi. Fakultas Psikologi Universitas Islam Negeri Sultan Syarif Kasim, Riau, Pekanbaru.

Halpern J, Cohen M, Kennedy G, Reece J, Cahan C, Baharav A (2014). Yoga for improving sleep quality and quality of life for older adults. Altern Ther Health Med. 20(3):37-46.

Irianto K (2015). Kesehatan Reproduksi Teori dan Praktikum Edisi 1. Bandung: Alfabeta.

Lebang E (2013). Yoga Sehari-hari. Jakarta: Pustaka Bunda.

Lestari (2010). Seluk Beluk Menopause. Jogjakarta: Gerai Ilmu.

Maryam S (2008). Mengenal Usia Lanjut dan Perawatannya. Jakarta: Salemba Medika.

Moilanen J, Aalto AM, Hemminki E, Aro AR, Raitanen J, Luoto R (2010). Prevalence of menopause symptoms and their association with lifestyle among Finnish middle-aged women. Maturitas. 67(4): 368-374. doi: 10.1016/j.maturitas.2010.08.007

Nurdiati, Detty S, Rahmat I (2015). Pengaruh senam yoga terhadap kualitas tidur pada wanita pascamenopause di Panti Sosial Tresna Werdha Dinas Sosial Daerah Istimewa Yogyakarta.

Nursalam (2008). Manajemen Keperawatan, Aplikasi Dalam Praktik Keperawatan Profesional. Jakarta: Salemba Medika.

Ohayon MM, Krystal A, Roehrs TA, Roth T, Vitiello MV (2010). Using difficulty resuming sleep to define nocturnal awakenings. Sleep Med. 11(3): 236241. doi: 10.1016\%2Fj.sleep.2009.11.004.

PERMI Jawa Barat (2013). Paradigma Terkini Pengelolaan Menopause Menuju The Golden Age. Buku Kumpulan Makalah Simposium Nasional Menopause.

Proverawati A, Sulistyawati, Emi (2010). Menopause dan Sindrome Premenopause I edn W Kristiyanasari ed. Yogyakarta: Mulia Medika.

Sabatini T (2016). Faktor-Faktor yang berhubungan dengan kesiapan wanita premenopause dalam menghadapi menopause di Kelurahan Patangpuluhan Kecamatan Wirobrajan Kota Yogyakarta. Universitas Muhammadiyah Yogyakarta

Shindu P (2013). Hidup Sehat dan Seimbang dengan Yoga. Bandung: Qanita.

Suparni IE, Astutik RY (2016). Menopause Masalah dan Penanganannya Edisi 1. Yogyakarta: Deepublish 
Indonesian Journal of Medicine (2019), 4(3): 278-284

https://doi.org/10.26911/theijmed.2019.04.03.11

Wijayanti D, Husein AN, Arifin S (2014).

Gambaran Kejadian insomnia pada wanita menopause di kelurahan teluk dalam tahun 2013: kajian berdasarkan usia responden dan lama meno-

pause. Berkala Kedokteran. 10(2): 133-142

Women's Health Concern (2015). Menopause: Giving you confidence for understanding and action. 